\title{
"Why do financial services companies pay dividend? Evidence from Qatar Stock Exchange"
}

\begin{tabular}{|c|c|}
\hline AUTHORS & $\begin{array}{l}\text { Sumathi Kumaraswamy } \\
\text { Bora Aktan (D https://orcid.org/0000-0002-1334-3542 } \\
\text { Zainab Hafedh Al Halwachi }\end{array}$ \\
\hline ARTICLE INFO & $\begin{array}{l}\text { Sumathi Kumaraswamy, Bora Aktan and Zainab Hafedh Al Halwachi (2017). } \\
\text { Why do financial services companies pay dividend? Evidence from Qatar Stock } \\
\text { Exchange. Investment Management and Financial Innovations, 14(3), 389-403. } \\
\text { doi:10.21511/imfi.14(3-2).2017.09 }\end{array}$ \\
\hline DOI & http://dx.doi.org/10.21511/imfi.14(3-2).2017.09 \\
\hline RELEASED ON & Friday, 01 December 2017 \\
\hline RECEIVED ON & Thursday, 28 September 2017 \\
\hline ACCEPTED ON & Friday, 27 October 2017 \\
\hline LICENSE & $\begin{array}{l}(c) \text { EY-No } \\
\text { This work is licensed under a Creative Commons Attribution-NonCommercial } 4.0 \\
\text { International License }\end{array}$ \\
\hline JOURNAL & "Investment Management and Financial Innovations" \\
\hline ISSN PRINT & $1810-4967$ \\
\hline ISSN ONLINE & $1812-9358$ \\
\hline PUBLISHER & LLC "Consulting Publishing Company "Business Perspectives" \\
\hline FOUNDER & LLC "Consulting Publishing Company "Business Perspectives" \\
\hline
\end{tabular}

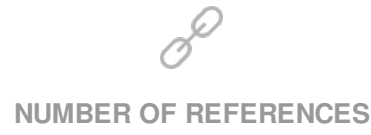

50

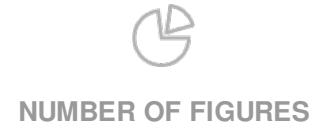

0

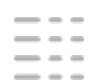

NUMBER OF TABLES

13

(C) The author(s) 2022. This publication is an open access article. 


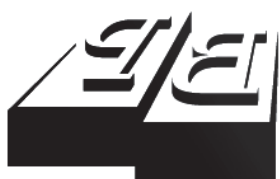

BUSINESS PERSPECTIVES

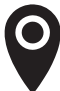

LLC "CPC "Business Perspectives” Hryhorii Skovoroda lane, 10, Sumy, 40022, Ukraine

www.businessperspectives.org

Received on: $28^{\text {th }}$ of September, 2017 Accepted on: $27^{\text {th }}$ of October, 2017

(c) Sumathi Kumaraswamy, Bora Aktan, Zainab Hafedh Al Halwachi, 2017

Sumathi Kumaraswamy, Dr. Assistant Professor, University of Bahrain, Bahrain.

Bora Aktan, Dr., Associate Professor, University of Bahrain, Bahrain.

Zainab Hafedh Al Halwachi, MBA, Bank of Bahrain and Kuwait, Bahrain.

\section{(ㄷ)(1) (8)}

This is an Open Access article, distributed under the terms of the Creative Commons Attribution-NonCommercial 4.0 International license, which permits re-use, distribution, and reproduction, provided the materials aren't used for commercial purposes and the original work is properly cited.
Sumathi Kumaraswamy (Bahrain), Bora Aktan (Bahrain),

Zainab Hafedh Al Halwachi (Bahrain)

\section{WHY DO FINANCIAL SERVICES COMPANIES PAY DIVIDEND? EVIDENCE FROM QATAR STOCK EXCHANGE}

\begin{abstract}
This study identifies the dividend policy determinants of banks and other financial institutions listed on Qatar Stock Exchange (QSE) for a period from 2009 to 2015 through studying the impact on eight factors on banks' dividends per share. Three models were adopted to investigate the determinants of the dividend policy and the factors that affect a bank's decision to pay out dividends. The findings indicate that the previous year's dividends per share, earnings per share, cash flow per share, firm size and return on average equity are positively related to the current year's dividends per share, as hypothesized. The study shows that the leverage position, bank's life cycle and growth opportunities are negatively related to the dividend payment. The study also reveals that banks and financial institutions in Qatar do a bit of "earnings smoothing" when comparing the earnings figures with the cash flow.
\end{abstract}

Keywords

JEL Classification earnings, dividend policy, banks, financial institutions, Qatar

G2, G21, G22, G35

\section{INTRODUCTION}

Dividend policy, along with its related decisions, remains one of the frequently researched areas in finance. Given that profit and shareholders' value maximization are the core economic and financial targets that companies seek to satisfy, dividend policy stays on the top of researches. With an attempt to maximize shareholders' wealth, financial managers seek to assess and trigger the optimal level of dividends that would entail satisfying shareholders, in which they have to tradeoff between payouts and retentions. Many propositions developed by numerous researchers to understand the payout policy have led to different and, in many cases, contradicting findings. Black (1976) referred to dividends as a "puzzle" to describe the uncertainty inherited in the divided policy, for which he argued that the more analysts look into the dividend policy issue, the more it gets complicated to generalize or comprehend its determinants. Black's (1976) dividends puzzle theory was supported by Bhattacharyya (2007) who adopted a different approach to understand the dividends theory through means of developing a model that links the retention ratio with executive management compensations and hypothesized a positive association between them in an equilibrium situation. Bhattacharyya (2007) found that dividends issue remains as an unsolved and complicated puzzle. DeAngelo and DeAngelo (2006) criticized Miller and Modigliani (1961) irrelevance theory of dividends payout to firms and investors' value and wealth, as they suggested that the theory resulted in restricting researchers' view about dividends payout, and, hence, they disagree with Black 
(1976) and Bhattacharyya (2007) for classifying dividends as an unsolved "puzzle". Extensive previous research works have been conducted to examine the dividend policy in developed countries, relatively a few similar studies have been used to understand emerging countries' payouts policies and its determinants.

Qatar, which was reclassified by Morgan Stanley Capital International (MSCI), Standard \& Poor's (S\&P) and Dow Jones Indices in 2014 from a frontier risky market to an emerging market, is one of the countries that one can hardly find any dividend policy studies conducted on. Given the recent reclassification, more of investors' attention is expected to be drawn on Qatar financial market behavior. Hence, this study intends to fill a gap with this respect.

The main objectives of the present empirical study are:

1. To apply Lintner's dividend model (1956) on banks and financial institutions listed on Qatar Stock Exchange (QSE) to examine the impact of lagged dividends and profitability on banks' dividend policy.

2. To investigate the impact of cash flows per share on banks' dividends.

3. To ascertain and examine the impact of other dividend policy determinants on the dividend payment.

4. To examine the factors that would affect a firm's probability to pay out dividends.

The remaining sections of the present study are organized as follows: section 1 provides a literature review of previous similar empirical studies conducted on emerging markets generally and others conducted on the banking sector specifically. Section 2 presents a brief overview of Qatar's banking sector. Section 3 and 4 describe the variables and data used in the study. Section 5, 6, 7, 8 and 9 present the empirical findings and analyze the results. Final section provides a short summary and concludes the study.

\section{PREVIOUS STUDIES}

Although the controversial issue of dividend policy has been a major focus of many researchers who developed multiple models, theories and pursued numerous empirical studies to understand the payout decisions and dividends determinants, the key credit is directed to Lintner (1956). Lintner (1956) was the first to attempt to formulate a model for the potential dividend payment determinants, in which he conducted interviews with 28 companies' managers and found that the two main factors are the current year earnings and the lagged dividends payment. On the other hand, Miller and Modigliani (1961) theory indicates when perfect and complete market conditions are satisfied, in which there are no taxes or transaction or agency costs and all firms are classified into the same risk level, the dividend policy does not matter, as it does not result in any impact on the shareholders' wealth or firm value. The first examination of Lintner's model on emerging markets was done by Mookerjee (1992) who prepared an empirical study on Indian stock market and found that Lintner's model well explains the behavior of the studied companies' dividends. The study cov- ered a period of 33 years, from 1949 to 1981, in which firms were found to be over-focused on the essentiality of dividend payment, no matter how the performance of the company was, even if it needed external borrowing. Another study carried out on Bursa Malaysia by Nassir and Mohamed (1993) concluded that, as proposed by Lintner (1956), firms maintain a target payout ratio based on the long-term sustainable profitability.

From Middle East context, according to Al Yahyaee (2006) who studied the dividend policy of financial and non-financial firms in Oman, both types of firms are affected by profitability, firm size and business risk. However, the dividend policy of the nonfinancial sector is significantly affected by leverage, age and government ownership, while the financial firms are not affected by those factors. Moreover, AlMalkawi (2007) who examined the behavior of all the firms listed on Amman Stock Exchange (Jordan) for a period from 1989 to 2000 agreed that size, age and profitability of firms have a significant positive relationship with the dividend policy. However, the study found that dividend policy is negatively related to leverage, a finding that is agreed by Al Kuwari 
(2009) who used a panel data of Gulf Co-operation Council (GCC) listed non-financial firms for a fiveyear period.

Some empirical studies had a concentrated scope on the dividend policy determinants specifically in the banking sector. Of the first researchers who limited their study scope to the banking sector are Gupta and Walker (1975). They conducted their research on a sample of 980 banks during 1965-1968 and revealed that there is a positive association between dividends and current year earnings, earnings variation from one year to another, cumulative earnings and total assets growth. On the contrary, negative associations exist between dividends and liquidity position. Lee (2009) examined the dividend policy determinants of Korean banks from 1994 to 2005 and found that there exists a positive association between banks' dividend payout ratio and their size and profitability. Kinfe (2011) investigated the dividend payout determinants for a sample of six banks in Ethiopia from 2006 up to 2010 using Lintner's model, where the results showed that the dividend payout ratio is positively related to firm size, negatively related to liquidity, while is unaffected by growth, profitability or leverage. A similar study by Marfo-Yiadom and Agyei (2011) on sixteen banks in Ghana for the years 1999-2003 concluded that the dividend policy is significantly and positively affected by leverage, profitability, collateral capacity and changes in the dividend payment. However, maturity and growth were found to have a significant negative impact on the payout ratio. Maladjian and El Khoury (2014) who conducted a study to reveal the determinants of dividend payout ratio by examining four Lebanese banks listed in Beirut Stock Exchange concluded that the lagged dividend payment positively affects the dividend policy and is found to be the most important variable. The study also found that firm size and risk profile have a significant positive relationship with dividend payout, while the profitability and growth have a significant negative relationship.

\section{FINANCIAL SERVICES INDUSTRY IN QATAR}

According to Qatar Country Report (2015) which is published by the Multiples Groups, and the Global Finance Magazine (2015), Qatar was ranked as the richest country in the world in terms of Gross
Domestic Product (GDP) per capita, based on the Purchasing Power Parity (PPP) per capita, indicating that Qatar is a rewarding country for investments, which could lead to attracting more capital investments. Qatar's banking sector continues to grow and its contribution to the country's GDP is noticeably increasing in the recent past. The ratio of Qatar's total banking sector's assets to the GDP increased from 97\% in 2008 to $127 \%$ in June 2013. Qatar banking sector is composed of 18 banks, 13 of which are listed on Qatar Stock Exchange (QSE). Seven of the banks are foreign banks, while the remaining eleven banks are locally incorporated and are segregated between conventional banks, Islamic banks, along with a government owned bank which has a specialized license category, which is Qatar Development Bank (QDB). Qatar's banking sector assets are highly concentrated with the five largest banks accounting for around $77.8 \%$ of the total assets as of June 2013.

\section{HYPOTHESES DEVELOPMENT, DATA AND METHODOLOGY}

The main objective of the analysis is to test the relationship $\mathrm{b}$ etween the dividends paid by banks and financial institutions and the selected independent variables. Following is the F-test hypothesis for the overall model:

H0: There is no statistically significant relationship between the dividends payment and the lagged DPS, EPS, CFPS, ROAE, SIZE, $A G E, R E V G$ and $L R$.

H1: There is a statistically significant relationship between the dividends payment and at least one of the variables, the lagged DPS, EPS, CFPS, ROAE, SIZE, AGE, REVG and LR.

However, the significance of each of the independent variable will be tested separately.

\section{DATA SOURCES}

To examine the dividend policy determinants of Qatar's banks and other financial institutions, a database is constructed using unbalanced panel method. 
The unbalanced panel data were used, as all banks and financial institutions should meet one criterion: being listed on the stock exchange and having published annual reports for the selected period. One bank failed to meet this criterion and therefore has been excluded from the study. Many previous studies have used the unbalanced panel estimation, including Omet (2004) and Al Ajmi and Abo Hussain (2011). Panel techniques were recommended by Baltagi (2001) who points out to the effectiveness of panel data, as it takes into account the heterogeneity that avails among individual banks, and enables to conduct the study of different factors with enhanced efficiency and less collinearity. Maladjian and El Khoury (2014) provided similar recommendations for the panel techniques as well. The sample size includes 12 firms for the prior mentioned period, totaling 84 observations. The data were collected from the firms' specific annual reports.

\section{DEFINITION OF DEPENDENT AND INDEPENDENT VARIABLES}

\section{RESEARCH MODELS}

Based on the previous literatures, three research models are developed to test the hypotheses developed so far. The impact of a number of variables on the Dividends per Share (DPS) of Qatar's banks and financial institutions in a given year is investigated. Fixed Effect Pool Panel Regression is employed to identify the most significant determinants of dividend payments in the banks and financial institutions in Qatar and to test the developed hypotheses using the models shown below.

\section{Model A}

The first model that attempted to identify the dividend policy determinants is the Lintner model (1956). According to the model, each company has a target dividend payout ratio. The targeted dividend level $(D \cdot t)$ is dependent on the pre-determined target payout ratio $(r)$, and the firm's earnings for the year $\left(E_{t}\right)$, as follows:

$$
D \cdot t=r \cdot E_{t} \text {. }
$$

Table 1. Independent variables definitions and expected relationship with the dependent variable

\begin{tabular}{|c|c|c|c|}
\hline Variable & Abbreviation & Definition & Expected sign \\
\hline Previous Year's Dividends & PYDPS & Previous Year Dividends per Share & Positive (+) \\
\hline Profitability Measure (1) & EPS & Earnings per Share & Positive (+) \\
\hline Profitability Measure (2) & ROAE & Net Income/Average Shareholder's Equity & Positive (+) \\
\hline Cash Flow & CFPS & Cash Flow per Share & Positive (+) \\
\hline Size & SIZE & Natural Logarithm of Total Assets & Positive (+) \\
\hline Life Cycle & AGE & Retained Earnings/Common Equity & Positive (+) \\
\hline Growth Opportunities & REVG & $\begin{array}{l}\text { Revenue Growth: (Current Year Revenue - Previous } \\
\text { Year's Revenue)/(Previous Year's Revenues) }\end{array}$ & Negative (-) \\
\hline Leverage Position & LR & Leverage Ratio: Debt/Total Assets & Positive (+) / Negative (-) \\
\hline
\end{tabular}


According to Lintner, dividend level should be gradually adjusted to the targeted payout ratio, and firms' management will curtail or eliminate dividends only in extreme circumstances or as a last resort.

Accordingly, the difference between two consecutive year's dividend levels is represented by:

$D_{t}-D_{t-1}=\alpha+c \cdot\left(D \cdot t-D_{t-1}\right)+e t$,

where $D_{t}$ - current period's dividends per share; $D_{t-1}$ - previous period's dividends per share; $\alpha$ reluctance to curtail dividends; $c$ - adjustment factor; $e$ - error term.

By substituting equation (1) in equation (2), we get:

$D_{t}-D_{t-1}=\alpha+c \cdot r \cdot E_{t}-c \cdot D_{t-1}+e t$.

By rearranging the equation, we get the current period's dividends per share as follows:

$D_{t}=\alpha+c \cdot r \cdot E_{t}+(1-c) \cdot D_{t-1}+e t$.

We therefore arrive to Lintner's basic model, which is the regression format that will be studied separately (model $\mathrm{A})$ :

$D P S_{t}=\alpha+B_{0} \cdot D P S_{t-1}+B_{1} \cdot E P S_{t}+e t$.

A modified version of Lintner's basic model (modified model A) will be used in the present study, in which the EPS in equation (5) will be replaced by CFPS to examine the impact of cash on a firm's dividend paying capacity.

\section{Model B}

Model B is as an extension of model A and includes all the independent variables discussed in section 4 as follows: Previous Year's Dividends per Share (PYDPS), Earnings per Share (EPS), Firm Size (SIZE), Firm Life Cycle (AGE), Return on Average Equity (ROAE), the Leverage Position (LR) and Growth Opportunities (REVG).

A modified version of model $B$ which is referred to in the present study as modified model $\mathrm{B}$ includes all of the variables included in model B, except for replacing the EPS with cash flow per share (CFPS).

\section{Model C}

Model C tries to identify the factors that would impact a company's likelihood to pay out dividends, and includes the same independent variables identified in model B. Given the purpose of model C, in which factors affecting a firm's payment of dividends are to be identified, and to account for the nature of the dependent variable (DPS), the logit model will be adopted.

\section{Regression}

Given the nature of the cross-sectional data collected for 7 years to conduct the study, and with an attempt to control of the unobserved variables that influence the dividend payments and its policies, the pooled panel regression was adopted.

\section{Hausman test}

Panel data regression model includes two variations, which are the fixed effects and the random effects. The Hausman test was run using the Stata tool to determine whether the fixed or random effects fit the study data. The following table (Table 2) shows the data.

\section{Table 2. Results of the Hausman test}

HO: Random effects panel data are preferred

H1: Fixed effects panel data are preferred

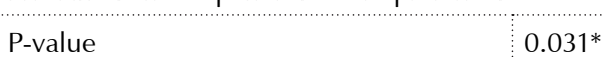

Conclusion

Reject the null hypothesis. The fixed effects panel data regression is preferred.

Note: ${ }^{\star}$ significant at $5 \%$.

Therefore, the fixed effect pool panel regression will be implemented in the study, especially that it is the preferred model to control for unobservable variables.

\section{ANALYSIS OF DATA SPECIFICATIONS AND CHARACTERISTICS}

In order to detect the characteristics and the nature of the regressed data, tests including residuals normal distribution, homoscedasticity, serial correlation, multicollinearity and linearity were used. 
Table 3. Pearson correlation matrix

\begin{tabular}{|c|c|c|c|c|c|c|c|c|c|}
\hline Variable & DPS & PYDPS & EPS & CFPS & SIZE & LR & AGE & ROAE & REVG \\
\hline DPS & 1.0000 & & & & & & & & \\
\hline PYDPS & 0.6442 & 1.0000 & & & & & & & \\
\hline EPS & 0.6312 & 0.6421 & 1.0000 & & & & & & \\
\hline CFPS & 0.6011 & 0.6682 & 0.6733 & 1.0000 & & & & & \\
\hline SIZE & 0.6417 & 0.6348 & 0.6002 & 0.6239 & 1.0000 & & & & \\
\hline LR & 0.4313 & 0.4126 & 0.4473 & 0.4679 & 0.6580 & 1.0000 & & & \\
\hline AGE & 0.1961 & 0.1831 & 0.5426 & 0.4532 & 0.2457 & 0.1492 & 1.0000 & & \\
\hline ROAE & 0.4817 & 0.4198 & 0.5970 & 0.5533 & 0.3883 & 0.4510 & 0.4636 & 1.0000 & \\
\hline REVG & 0.1698 & 0.0317 & 0.2646 & 0.2346 & 0.2276 & 0.2170 & 0.1968 & 0.5853 & 1.0000 \\
\hline
\end{tabular}

\section{Test 1. Multicollinearity}

Two tests will be used to detect multicollinearity in this study; the Pearson correlation test and the Variance Inflation Factor (VIF). Table 3 below presents the results of the Pearson correlation test. Given that no correlation between the independent variables is above 0.75 (Malhotra, 2004), we conclude multicollinearity is not a serious issue.

Table 4 below presents the results of the VIF tests, where test 1 includes the CFPS along with the other independent variables, and test 2 includes the EPS instead. As indicated by Chatterjee and Price (1977), VIF coefficient that is greater than 10 is considered as an indication for the presence of multicollinearity. As observed from the table below, the calculated VIFs are well below the limit of 10 , and hence we can conclude that no strong correlation exists between the independent variables, which supports the findings of the Pearson tests.

Table 4. Results of the Variance Inflation Factor (VIF)

\begin{tabular}{l|c|c}
\hline \multicolumn{1}{c|}{ Variables } & VIF test 1 & VIF test 2 \\
\hline DPS & 5.32 & 5.53 \\
\hdashline PYDPS & 4.61 & 4.95 \\
\hdashline CFPS & 5.80 & - \\
\hdashline EPS & - & 5.66 \\
\hdashline SIZE & 2.73 & 2.78 \\
\hline LR & 1.79 & 1.85 \\
\hline AGE & 1.70 & 2.12 \\
\hdashline ROAE & 2.43 & 2.52 \\
\hline REVG & 1.70 & 1.73 \\
\hdashline Mean VIF & 3.26 & 3.39 \\
\hline
\end{tabular}

\section{Test 2. Homoskedasticity}

Two tests will be conducted to test homoscedasticity. Koenker test and White test. P-values greater than 0.05 level of significance result in not rejecting the null hypothesis. Table 5 below shows that the $\mathrm{p}$-values resulting from both tests are greater than 0.05 , indicating that there is homoscedasticity and the error variance is constant across all independent variables. Therefore, no corrective measures have to be taken.

Table 5. Results of Koenker test and White test

\begin{tabular}{|c|c|c|}
\hline Test & P-value & Conclusion \\
\hline \multicolumn{3}{|c|}{ HO: Constant Error Variance (Homoskedasticity) } \\
\hline \multicolumn{3}{|c|}{ H1: Non-constant Error Variance (Heteroskedasticity) } \\
\hline Koenker test & 0.212 & \multirow{2}{*}{$\begin{array}{l}\text { Cannot reject that } \\
\text { the error variance } \\
\text { is constant }\end{array}$} \\
\hline White test & 0.336 & \\
\hline
\end{tabular}

\section{Test 3. Serial correlation}

This assumption states that the error terms (disturbances) have independent distribution, where the correlation and covariance of the different residuals are zero. For the purpose of testing residuals autocorrelation, the Wooldridge test (2002) will be conducted, given that it fits the data model used in this study, which are the unbalanced panel data.

Table 6 presents the results of the Wooldridge test, where the significance statistics indicate that residuals autocorrelation does not present in the study. As the p-value resulting from the test is greater than 0.05 , the null hypothesis cannot be rejected, and we therefore conclude that serial correlation does not present in this study. 
Table 6. Results of the Wooldridge test

\begin{tabular}{l}
\hline H0: There is no first-order autocorrelation \\
H1: There is first-order autocorrelation \\
P-value \\
Conclusion \\
Cannot reject that there is no first-order autocorrelation. \\
\hline
\end{tabular}

\section{Test 4. Normally distributed error terms}

This test is conducted to detect whether the residuals are normally distributed. Violation for the residuals normality might lead to inefficient, or at worst, misleading parameters and results. In order to detect whether the error terms are normally distributed, Shapiro-Wilk test is used in this study. For the Shapiro-Wilk test, two extreme residuals outliers were excluded from the sample. Where the $p$-value resulting from running the test is greater than $5 \%$ level of significance, we accept the null hypothesis and conclude that the residuals are normally distributed. Table 7 shows the results of this test, where the p-value reported at 0.109 is greater than 0.05 . We therefore cannot reject that the sample is drawn from a population that is normally distributed.

Table 7. Shapiro-Wilk test results

\begin{tabular}{|c|c|c|c|}
\hline & Obs. & P-value & Conclusion \\
\hline \multicolumn{4}{|c|}{$\mathrm{HO}$ : Population is normally distributed } \\
\hline \multicolumn{4}{|c|}{$\mathrm{H} 1$ : Population is not normally distributed } \\
\hline $\begin{array}{l}\text { Unstandardized } \\
\text { Residual }\end{array}$ & 82 & 0.109 & \multirow{2}{*}{$\begin{array}{l}\text { Cannot } \\
\text { reject that } \\
\text { population } \\
\text { is normally } \\
\text { distributed }\end{array}$} \\
\hline $\begin{array}{l}\text { Standardized } \\
\text { Residual }\end{array}$ & 82 & 0.109 & \\
\hline
\end{tabular}

\section{EMPIRICAL RESULTS AND ANALYSIS}

\section{Descriptive statistics}

Table 8 presents the descriptive statistics of the dependent and independent variables, which will be used to analyze some variables' behaviors and conduct simple analysis. Given that we are concerned about the relationship between the CFPS and the DPS, in comparison to the EPS and DPS, we can observe that the average EPS account for 90.5\% of the average CFPS. Given that the mean EPS is smaller than the CFPS, the mean Dividends Payout Ratio (DPR) is higher on the basis of EPS in comparison to CFPS, which is $63.4 \%$ and $57.4 \%$, respectively. The two ratios being relatively close to each other provide an indication that the average reported earnings of the banks and financial institutions listed on QSE for the selected period are conservative in comparison to the cash flows and no noticeable deviation is observed.

Based on the reported statistics, the coefficient of variation $(\mathrm{CV})$ of the EPS is 0.88 and the $\mathrm{CV}$ of the CFPS is 0.90, which indicates that there is only a slightly higher variability in relation to the mean for the CFPS relative to the EPS. However, the variance ratio of the DPS over EPS is 0.30 $\left(2.01^{\wedge} 2 / 3.66^{\wedge} 2\right)$, and over CFPS is 0.24 , while the variance ratio of the EPS over CFPS is 0.80 . Given that the CV of the CFPS is slightly higher than the CV of EPS while the variance ratio of the EPS over the CFPS is found to be 0.80 , we can conclude that the studied firms and financial institutions exhibit a little degree of earnings smoothing.

Table 8. Variables descriptive statistics

\begin{tabular}{|c|c|c|c|c|c|c|c|c|c|}
\hline Description & DPS & PYDPS & EPS & CFPS & SIZE & $\mathbf{L R}$ & AGE & ROAE & REVG \\
\hline Mean & 2.65 & 2.84 & 4.18 & 4.62 & 23.27 & 0.72 & 0.08 & 0.13 & 0.08 \\
\hline Sdj & 2.01 & 2.2 & 3.66 & 4.1 & 2.31 & 0.25 & 0.09 & 0.07 & 0.24 \\
\hline Minimum & 0 & 0 & $(1.78)$ & $(0.95)$ & 18.57 & 0.21 & $(0.16)$ & $(0.15)$ & $(0.61)$ \\
\hline Maximum & 7.5 & 7.5 & 16.1 & 17.59 & 27.01 & 0.96 & 0.43 & 0.31 & 1.13 \\
\hline Coefficient of variation & 0.76 & 0.77 & 0.88 & 0.90 & 0.1 & 0.35 & 1.13 & 0.54 & 3 \\
\hline Skewness & 0.46 & 0.42 & 0.75 & 0.69 & $(0.51)$ & $(0.82)$ & 0.62 & $(0.75)$ & 0.51 \\
\hline
\end{tabular}


Table 9. Association between a firms' performance and its changes in the dividend payment

\begin{tabular}{|c|c|c|c|c|}
\hline Criteria & Loss-incurring firms & Profit increase & Profit decrease & Total \\
\hline \multirow{2}{*}{ DPS omission } & 2 & 5 & 1 & 8 \\
\hline & $67 \%$ & $8 \%$ & $6 \%$ & $10 \%$ \\
\hline \multirow{2}{*}{ DPS maintenance } & 0 & 20 & 4 & 24 \\
\hline & $0 \%$ & $32 \%$ & $22 \%$ & $29 \%$ \\
\hline \multirow{2}{*}{ DPS increase } & 0 & 26 & 1 & 27 \\
\hline & $0 \%$ & $41 \%$ & $6 \%$ & $32 \%$ \\
\hline \multirow{2}{*}{ DPS decrease } & 1 & 12 & 12 & 25 \\
\hline & $33 \%$ & $19 \%$ & $67 \%$ & $30 \%$ \\
\hline \multirow{2}{*}{ Total } & 3 & 63 & 18 & 84 \\
\hline & $4 \%$ & $75 \%$ & $21 \%$ & $100 \%$ \\
\hline
\end{tabular}

\section{RELATIONSHIP BETWEEN FIRMS' PERFORMANCE AND DPS CHANGES}

Table 9 reflects the association between a firm's performance and the changes in its dividend payment. The studied banks and financial institutions were split between two groups: loss-incurring and profit-generating. In order to better understand the behavior of firms, a distinction was made between profitable firms that witnessed increase in profit, and those that had decreasing profits. The observations were subsequently divided into the three groups (loss incurring, profit increasing, and profit decreasing banks), along with the occurrences of dividends omission, maintenance, increase and decrease among those categories. As observed, the majority $(67 \%)$ of the loss-incurring firms omitted the payment of dividends in the year during which losses were reported. Of the profitable firms, only $7 \%$ of the two groups declined to pay dividends, $30 \%$ of them increased the DPS in comparison to the previous period, and an equivalent percentage maintained their DPS in the same period. With respect to the firms that witnessed profit increases, the majority (41\%) increased their dividend payment during the year of reported profit increase, and $32 \%$ of which maintained their dividends lev$\mathrm{el}$, while only $8 \%$ did not pay any dividends during the years with profit increases. However, the majority $(67 \%)$ of the firms that reported decreases in profit reduced their DPS level and $22 \%$ of which maintained their level of dividends. Those findings indicate that of the profitable firms, firms reporting profit increases tend to either increase or maintain their dividends level, while firms reporting profit decrease tend to either decrease or maintain their dividend level. This finding is supported by Al Ajmi and Abo Hussain (2011).

\section{Model (A). Linter's model \& modified Lintner's model - empirical results}

Table 10 below presents the regression results of the Lintner's model and the modified version of it. The results indicate that for model (A), the coefficient of PYDPS is positively related to the DPS and is highly significant. This result is consistent with the findings of similar studies conducted on emerging markets, including the study of Al Ajmi and Abo Hussain (2011) on firms listed on the Saudi Securities Market, as well as Maladjian and El Khoury (2014) on banks listed on the Beirut Stock Exchange. Additionally, the coefficient of EPS is also positive and highly statistically significant, which supports the findings of several studies, including Wei et al. (2003), Bodla et al. (2007) and Pandey and Bhat (2007).

The results of the modified model (A) represented below show that both the PYDPS and CFPS have coefficients with positive signs, and are highly significant, which is consistent with the findings of Andres et al. (2009) and Al Ajmi and Abo Hussain (2011).The results of model (A) and its modified version clearly outline the importance of the PYDPS, EPS and CFPS on determining the current period's dividends. 
Table 10. Results of Lintner's model (model $(A)$ and (modified model (A)

\begin{tabular}{|c|c|c|c|c|}
\hline \multirow{2}{*}{ Variable } & \multicolumn{2}{|c|}{ Model (A) } & \multicolumn{2}{|c|}{ Modified model (A) } \\
\hline & Coefficient & P-value & Coefficient & P-value \\
\hline PYDPS & 0.506 & $0.000^{* * *}$ & 0.466 & $0.000^{* * *}$ \\
\hline EPS & 0.183 & $0.002 * * *$ & & \\
\hline CFPS & & & 0.180 & $0.002^{* * *}$ \\
\hline $\begin{array}{l}\text { Durbin-Watson (DW) } \\
\mathrm{R}^{2}\end{array}$ & \multicolumn{2}{|c|}{$\begin{array}{l}2.179 \\
0.725\end{array}$} & \multicolumn{2}{|c|}{$\begin{array}{l}2.177 \\
0.722\end{array}$} \\
\hline Adjusted R2 & \multicolumn{2}{|c|}{0.718} & \multicolumn{2}{|c|}{0.715} \\
\hline
\end{tabular}

Note: ${ }^{* *}$ significant at $1 \%$.

DW test statistic that is approximately equal to 2 indicates that the error terms are homoscedastic and not serially correlated. To provide a further support to the homoscedasticity test conducted, the above DW test statistic was compared against the DW critical values which are $\left(d_{L}=1.60 ; d_{u}=1.70\right)$, as both DW values obtained from the regression fall between $\left(d_{u}=1.7 ; 4-d_{u}=2.3\right)$. Therefore, we can safely conclude that there is no serial correlation in both models.

\section{Model (B). Extended Lintner's model empirical results - dividend payment determinants}

Table 11 below presents the results of the extended Lintner's model, which is conducted on two versions to gauge the relationship between different variables and a firm's dividend payment: one including the EPS and the other independent variables which are previous year's DPS, the size, firm's leverage level, age of the firm, ROAE, and revenue growth, while the second one includes CFPS instead of the EPS, along with the other independent variables. The findings are discussed below.

\section{Previous Year's Dividends per Share (PYDPS)}

The results of both versions of model (B) support the findings of model (A), in which the coefficient of the PYDPS is positively related to the current year DPS, and is highly statistically significant, which indicates that the DPS has a positive relationship with the PYDPS, as expected. This finding indicates that the lagged dividends per share are important determinants of the dividends paid by banks and financial institutions in Qatar in any given year, which supports that those banks are reluctant to express inconsistency or deductions in the level of their dividends, which might lead to unsatisfied shareholders that do not have confidence in the banks' ability to generate stable earnings that allow them to distribute dividends, and hence resulting in an adverse impact on the bank's image.

\section{Earnings per Share (EPS) and Cash Flow per Share (CFPS)}

Similar to the findings of model (A) and its modified version, the EPS and CFPS coefficients are positively related to the current year DPS and are highly significant. This provides a strong signal of the importance of those variables in determining the DPS, in which the likelihood of paying dividends increases with the EPS and CFPS, as hypothesized. Given that the earnings of banks are split between retained earnings and dividends, higher earnings indicate higher banks' ability to pay out dividends, as the earnings generated would be sufficient to pursue activities using internal financing with retained earnings, as well as distributing dividends out to shareholders. The finding can also provide support to the signaling theory, in which firms tend to distribute dividends back to shareholders to signal that they are healthy, enjoy a solid financial position, and are able to generate sufficient earnings. Therefore, the more earnings generated, the more the dividend payment.

\section{Firm Size (SIZE)}

While the firm size is found to have a positive coefficient sign as expected, it has a non-significant relationship with the DPS. This finding is in-line with Al Ajmi and Abo Hussain (2011) but contra- 
dicts with Aivazian et al. (2006) who, based on his study findings, found that there is a significant positive relationship between size and dividend payment, and Ben Naceur et al. (2006) who found that dividends are negatively related to firm size. The positive relationship indicates that as banks and financial institutions in Qatar grow in size, as they win more creditor's trust and confidence in their ability to owe their obligations, and hence they become more able to obtain external financing at more favorable financing cost in comparison to smaller banks, becoming less reliant on internal financing and therefore having higher ability to pay out dividends. However, a probable reason for the non-significant relationship between size and DPS can be attributed to the fact that since all banks and financial institutions in Qatar, and regardless of their size, are monitored and governed by the Central Bank of Qatar (CBQ), they should follow the CBQ policies and rules.

\section{Leverage Ratio (LR)}

Banks and financial institutions' leverage position is found to be negatively related to dividends. However, both versions of the regression results reveal that leverage is non-significant and hence is not considered as one of the DPS determinants, which contradict with what was reported by Agrawal and Narayanan (1994) and Aivazian et al. (2006). However, similar findings were reported by Al Ajmi and Abo Hussain (2011).The negative relationship between the leverage position and dividends could be due to two reasons. First, as banks become more highly leveraged, bondholders tend to impose higher restrictions on their earnings in order to be consistently able to service the committed fixed financing cost, and hence the leverage position negatively affects dividend payment. Second, following the financial crisis of 2007, the Bank for International Settlement (BIS) imposed additional restrictions on banks to enhance their financial position and increase their stable funds. Therefore, banks may have started taking the necessary measures in order to be able to meet the additional restrictive rules and regulatory buffers once they become compulsory, and hence lowering their dividend distribution and increasing their earnings retention. The non-significant relationship between the leverage position and the DPS could be justi- fied by the common nature of the core business activities carried out by all banks and financial institutions, in which they function as an intermediary between those with excess funds (lenders), and others who are in shortage (borrowers). Hence, the leverage position could be considered to not being unique to specific bank, and varies at a lower range, and is therefore excluded from being a significant explanatory variable to the DPS.

\section{Firm Age (AGE)}

Age, measured in this study by the retained earnings relative to common equity, was found to be negatively related to DPS, which indicates that chances for dividend payment decrease as a bank moves along the life cycle, a finding that contradicts our expectation of the existence of a positive relationship. The coefficient of the AGE is statistically significant and hence is one of the determinants of the dividend payments. The negative relationship found could be explained by the availability of many opportunities in the market; the more banks become well-established, the more they have unique branding and strong image in the eyes of customers and investors, the more they become able to enforce their strong existence in the market, the more they can go ahead with profitable expansion opportunities driven by the long history and strong relationship with customers and investors.

\section{Return on Average Equity (ROAE)}

As hypothesized, the ROAE as another measure of firm profitability was found to be positively related to DPS. However, according to Table 11 below, ROAE is non-significant and hence is not a determinant of the dividend payment. This finding contradicts with Maladjian and El Khoury (2014) who found that ROAE is negatively related to DPS. As the ROAE is a measure of profitability, its positive relationship with the DPS was expected. The higher ROAE level that a bank can stand at, the more profitable it is deemed to be. The positive relationship is also expected by shareholders, as it indicates the bank's ability to generate more earnings per a currency invested by the shareholders in its capital, and consequently, the higher its ability in distributing dividends to shareholders. 
Table 11. Results of Lintner's extended model (model (B)) and modified extended model (B)

\begin{tabular}{|c|c|c|c|c|}
\hline \multirow{2}{*}{ Variable } & \multicolumn{2}{|c|}{ Model (B): extended lintner's model } & \multicolumn{2}{|c|}{ Model (B): modified extended Lintner's model } \\
\hline & Coefficient & P-value & Coefficient & P-value \\
\hline Constant & -1.283 & 0.466 & -1.534 & 0.393 \\
\hline PYDPS & 0.378 & $0.003^{* * *}$ & 0.395 & $0.004^{* * *}$ \\
\hline EPS & 0.233 & $0.014 * *$ & & \\
\hline CFPS & & & 0.174 & $0.044^{* *}$ \\
\hline SIZE & 0.080 & 0.361 & 0.091 & 0.307 \\
\hline LR & -0.093 & 0.886 & -0.183 & 0.781 \\
\hline AGE & -4.004 & $0.042^{* *}$ & -2.820 & $0.036^{* *}$ \\
\hline ROAE & 3.112 & 0.255 & 3.712 & 0.179 \\
\hline REVG & -0.021 & 0.975 & -0.020 & 0.976 \\
\hline $\mathrm{R}^{2}$ & 0.750 & & 0.743 & \\
\hline $\begin{array}{l}\text { Adjusted } R^{2} \\
\text { Durbin-Watson (DW) } \\
\text { F-test p-value }\end{array}$ & \multicolumn{2}{|c|}{$\begin{array}{c}0.727 \\
2.152 \\
0.000^{* * *}\end{array}$} & \multicolumn{2}{|c|}{$\begin{array}{c}0.720 \\
2.149 \\
0.000^{* * *}\end{array}$} \\
\hline
\end{tabular}

Note: ${ }^{\star}$ significant at $10 \%,{ }^{* *}$ at $5 \%$ and ${ }^{* * *}$ at $1 \%$.

\section{Revenue Growth (REVG)}

As hypothesized, revenue growth is negatively related to dividends. However, the REVG coefficient is non-significant and hence the growth opportunities is not a primary determinant for dividend payment. The revenue growth relationship with DPS is consistent with the assumption that the more opportunities available in the market, which vary from introducing new financing products, pursuing expansion opportunities locally, regionally and internationally, as well as expanding the banking network among others, the more the chance that a bank would retain a larger portion of its earnings as an internal cheaper source of financing, than paying out dividends. Hence, the negative relationship can be justified.
As can also be concluded from the regression results table, the $\mathrm{p}$-value of the F-test indicates that the overall model is highly significant in explaining the dependent variable (DPS). Owning to the results, and given that some of the regressed independent variables were found to be significant in determining the DPS, and with evidence from the F-test results that propose the overall model significance, there is no multicollinearity detected as the tests result support, and do not contradict, each other.

Table 12 below summarizes the relationship direction and significance of each independent variable, according to model (B) results.

Table 12. Summary of model (B) results of coefficients relationship direction and significance

\begin{tabular}{|c|c|c|c|}
\hline Variable & Expected relation direction & Results relation direction & Significance \\
\hline PYDPS & Positive (+) & Positive (+) & Significant \\
\hline EPS & Positive (+) & Positive (+) & Significant \\
\hline CFPS & Positive (+) & Positive $(+)$ & Significant \\
\hline SIZE & Positive (+) & Positive (+) & Non-significant \\
\hline LR & Positive (+)/Negative (-) & Negative (-) & Non-significant \\
\hline AGE & Positive (+) & Negative (-) & Significant \\
\hline ROAE & Positive (+) & Positive (+) & Non-significant \\
\hline REVG & Negative (-) & Negative (-) & Non-significant \\
\hline
\end{tabular}


Table 13. Results of model (C) - logit regression

\begin{tabular}{|c|c|c|c|c|}
\hline \multirow{2}{*}{ Variable } & \multicolumn{2}{|c|}{ Model (C): extended Lintner's model } & \multicolumn{2}{|c|}{ Model (C): modified extended Lintner's model } \\
\hline & Coefficient & P-value & Coefficient & P-value \\
\hline Constant & -6.27 & 0.278 & -8.613 & 0.172 \\
\hline PYDPS & 0.11 & $0.026^{* *}$ & 0.244 & $0.009 * * *$ \\
\hline EPS & 0.169 & $0.004^{* * *}$ & & \\
\hline CFPS & & & 0.192 & $0.016^{* *}$ \\
\hline SIZE & 0.454 & $0.036^{* *}$ & 0.559 & $0.032 * *$ \\
\hline LR & -0.049 & $0.031^{* *}$ & -0.047 & $0.042^{* *}$ \\
\hline AGE & 0.002 & 0.11 & 0.559 & $0.022^{* *}$ \\
\hline ROAE & 0.158 & 0.16 & 0.178 & $0.085^{*}$ \\
\hline REVG & -0.03 & 0.179 & -0.025 & 0.246 \\
\hline
\end{tabular}

Note: ${ }^{\star}$ significant at $10 \%,{ }^{* *}$ at $5 \%$ and ${ }^{* *}$ at $1 \%$.

\section{Model (C). Potential factors affecting banks' probability of dividend payment}

Model (C) attempts to identify the factors that would affect a bank's decision and probability to pay out dividends in a given year. As Table 13 below shows, the previous year's dividend payment, earnings per share, banks' size and leverage level are all statistically significant and hence do affect a bank's decision to pay out dividends. The results show that all of these variables have the hypothesized signs of the relationship with the dividends, as all had positive signs, except for the leverage ratio that is negatively related to dividends. The results of the modified model (C) where CFPS is used in place of EPS show similar findings. The only difference between the two versions of model (C) is that the modified version includes the bank's age, referring to its life cycle, as a significant factor positively affecting a bank's probability of paying dividends.

\section{CONCLUSION}

The main objective of the present study was to identify the dividend policy determinants of banks and financial institutions listed on Qatar Stock Exchange (QSE) for a period from 2009 to 2015, through studying the impact on eight factors on banks' dividends per share. The fixed effects pool panel regression was implemented to run models (A) and (B). The findings revealed that the previous year's dividends per share, earnings per share, cash flow per share, firm size and return on average equity are positively related to the current year's dividends per share, as hypothesized. The study also found that the leverage position, bank's life cycle and growth opportunities are negatively related to the dividend payment. The negative relationship between a bank's leverage position and its dividend payment was explained by the possibility of higher restrictions on earnings imposed by the debt-holders due to the committed fixed debt cost and the Bank of International Settlement (BIS) additional restrictive requirements for Basel III following the financial crisis 2007, in which banks were required to enhance their liquidity position and maintain higher amounts in stable funds, which could negatively affect banks' dividend payment. The negative relationship between the life-cycle and dividends was explained by the possibility of the availability of plentiful growth opportunities in the market.

However, only four factors were found to be significant, which are lagged dividends, earnings per share, cash flow per share and life cycle. The study also found that the majority of loss-incurring firms tend to omit dividend payment during the period of reported losses, while the majority of firms with increasing profits tend to either increase or maintain their dividends level, and the majority of decreasing profits firms were found to either decrease or maintain their dividends level. 


\section{LIMITATIONS AND FUTURE SCOPE FOR RESEARCH}

However, the present empirical study suffers from a number of limitations. First, due to the difficulty of obtaining Qatar firms' financial data from a trusted database, most of the figures were taken directly from the banks' annual reports, which resulted in limiting the scope of the study to one concentrated sector instead of covering all of Qatar's listed firms. Secondly, the study period can be considered relatively short. Moreover, only eight variables were examined in the present study. Based on the findings of this empirical study, further future studies can be pursued to address some other questions, including the impact of dividend policy on share price, the ex-dividend day share price behavior and impact based on actual events, the signaling theory of dividends, as well as how majority of investors value the cash dividends in comparison to bonus shares or share repurchases.

\section{REFERENCES}

1. Agrawal, A., \& Jayaraman, N. (1994). The dividend policies of all-equity firms: A direct test of the free cash flow theory. Managerial and Decision Economics, 15(2), 139-148. Retrieved from http://onlinelibrary.wiley.com/doi/10.1002/ mde.4090150206/full

2. Al-Ajmi, J., \& Abo Hussain, H. (2011). Corporate dividends decisions: evidence from Saudi Arabia. The Journal of Risk Finance, 12(1), 41-56. Retrieved from http:// www.emeraldinsight.com/doi/ abs/10.1108/15265941111100067

3. Alli, K. L., Khan, A. Q., \& Ramirez, G. G. (1993). Determinants of corporate dividend policy: A factorial analysis. Financial Review, 28(4), 523-547. Retrieved from http://onlinelibrary.wiley. com/doi/10.1111/j.1540-6288.1993. tb01361.x/full

4. Al-Kuwari, D. (2009).

Determinants of the Dividend Policy of Companies Listed on Emerging Stock Exchanges: The Case of the Gulf Cooperation Council (GCC) Countries. Global Economy \& Finance Journal, 2(2), 38-63. Retrieved from https:// papers.ssrn.com/sol3/Papers. cfm?abstract $\_$id $=1793150$

5. Al Yahyaee, K. (2006). Capital structure and dividend policy in a personal tax free environment: The case of Oman (Doctoral dissertation, University of New South Wales). Retrieved from http://www.google.com.bh/url?sa $=\mathrm{t} \& \mathrm{rct}=\mathrm{j} \& \mathrm{q}=\&$ esrc $=\mathrm{s} \&$ source $=\mathrm{we}$ b\&cd=1\&ved=0ahUKEwj1m52igp
rXAhVJWhoKHVLADlgQFggkM AA\&url=http\%3A\%2F\%2Funswo rks.unsw.edu.au\%2Ffapi\%2Fdatastream\%2Funsworks\%3A1659\%2F SOURCE02\&usg=AOvVaw2Atk6g VsJI6MZMSOfS9sBD

6. Alzomaia, T. S., \& Al-Khadhiri, A. (2013). Determination of dividend policy: The evidence from Saudi Arabia. International Journal of Business and Social Science, 4(1). Retrieved from http://fac.ksu.edu. sa/sites/default/files/deter._of_divid_in_sa_2.pdf

7. Aivazian, V., Booth, L., \& Cleary, S. (2003). Dividend policy and the organization of capital markets. Journal of multinational financial management, 13(2), 101-121. Retrieved from http://www.sciencedirect.com/science/article/pii/ S1042444X02000385

8. Amidu, M., \& Abor, J. (2006). Determinants of dividend payout ratios in Ghana. The journal of risk finance, 7(2), 136-145. Retrieved from http://www.emeraldinsight. com/doi/abs/10.1108/1526594061 0648580?journalCode $=$ jrf

9. Andres, C., Betzer, A., Goergen, M., \& Renneboog, L. (2009). Dividend policy of German firms: A panel data analysis of partial adjustment models. Journal of Empirical Finance, 16(2), 175187. Retrieved from http://www. sciencedirect.com/science/article/ pii/S0927539808000716

10. Ben Naceur, S., Goaied, M., \& Belanes, A. (2006). On the determinants and dynamics of dividend policy. International review of Finance, 6(1-2), 1-23. Retrieved from http://onlinelibrary.wiley.com/doi/10.1111/ j.1468-2443.2007.00057.x/full

11. Bhattacharyya, N. (2007). Dividend policy: a review. Managerial Finance, 33(1), 4-13. Retrieved from http://www. emeraldinsight.com/doi/abs/10.1 108/03074350710715773?journal Code $=\mathrm{mf}$

12. Black, F. (1976). The dividend puzzle. The Journal of Portfolio Management, 2(2), 5-8. Retrieved from http://www.fsegn.rnu.tn/ documents/Dividend\%20policy. pdf

13. Bodla, B. S., Pal, K., \& Sura, J. S. (2007). Examining application of Lintner's dividend model in Indian banking industry. The ICFAI Journal of Bank Management, 6(4), 40-59. Retrieved from http://www.iupindia.in/1107/IJBM_Lintner\%27s_ Dividend_Model_40.html

14. Brittain, J. A. (1966). Corporate dividend policy. Brookings institution, Washington, DC.

15. Brooks, C. (2014). Introductory econometrics for finance. Cambridge University Press.

16. Chatterjee, S., \& Price, B. (1977). Regression analysis by example. New York: Wiley.

17. DeAngelo, H., \& DeAngelo, L. (1990). Dividend policy and financial distress: An empirical investigation of 
troubled NYSE firms. The Journal of Finance, 45(5), 14151431. Retrieved from http:// onlinelibrary.wiley.com/ doi/10.1111/j.1540-6261.1990. tb03721.x/pdf

18. DeAngelo, H., DeAngelo, L., \& Skinner, D. J. (1992). Dividends and losses. The Journal of Finance, 47(5), 18371863. Retrieved from http:// onlinelibrary.wiley.com/wol1/ doi/10.1111/j.1540-6261.1992. tb04685.x/full

19. Dickens, R. N., Casey, K. M., \& Newman, J. A. (2002). Bank dividend policy: explanatory factors. Quarterly journal of Business and Economics, 3(12) Retrieved from http://www.jstor. org/stable/40473341

20. Fama, E. F., \& French, K. R. (2001). Disappearing dividends: changing firm characteristics or lower propensity to pay? Journal of Financial economics, 60(1), 3(43). Retrieved from https:// doi.org/10.1016/S0304405X(01)00038-1

21. Grullon, G., \& Michaely, R. (2002). Dividends, share repurchases, and the substitution hypothesis. The Journal of Finance, 57(4), 16491684. Retrieved from http://citeseerx.ist.psu.edu/viewdoc/downloa $\mathrm{d}$ ?doi=10.1.1.538.6732\&rep=rep1 \&type $=p d f$

22. Gupta, M. C., \& Walker, D. A. (1975). Dividend disbursal practices in commercial banking. Journal of Financial and Quantitative Analysis, 10(03), 515529. Retrieved from https://doi. org/10.2307/2330494

23. Higgins, R. C. (1972). The corporate dividend-saving decision. Journal of Financial and Quantitative Analysis, 7(02), 1527-1541. https://doi. org/10.2307/2329932

24. Ho, H. (2003). Dividend policies in Australia and Japan. International Advances in Economic Research, 9(2), 91100. https://doi.org/10.1007/ BF02295710

25. Holder, M. E., Langrehr, F. W., \& Hexter, J. L. (1998). Dividend policy determinants: An investigation of the influences of stakeholder theory. Financial management, 73-82.

26. Imran, K., Usman, M., \& Nishat, M. (2013). Banks dividend policy: Evidence from Pakistan. Economic Modelling, 32, 88-90. https://doi.org/10.1016/j.econmod.2013.01.041

27. Jensen, G. R., Solberg, D. P., \& Zorn, T. S. (1992). Simultaneous determination of insider ownership, debt, and dividend policies. Journal of Financial and Quantitative analysis, 27(02), 247-263. https:// doi.org/10.2307/2331370

28. Kania, S. L. (2005). What factors motivate the corporate dividend decision? American Society of Business and Behavioral Sciences E-Journal, 1(1), 95-107. Retrieved from http://citeseerx.ist.psu.edu/ viewdoc/download?doi=10.1.1.51 5.1509\&rep $=$ rep $1 \&$ type $=p d f$

29. Kinfe, T. (2011). Determinants of dividend payout: an empirical study on banking industry in Ethiopia, 2006-2010 (Unpublished Master Thesis). Addis Ababa University).

30. Lee, S. W. (2009). Determinants of dividend policy in Korean banking industry. Banks and Bank Systems, 4(1), 67-71. Retrieved from https://businessperspectives. org/media/zoo/applications/publishing/templates/article/assets/js/ pdfjs/web/2560

31. Lintner, J. (1956). Distribution of incomes of corporations among dividends, retained earnings, and taxes. The American Economic Review, 46(2), 97-113. Retrieved from http://www.jstor.org/stable/1910664

32. Maldajian, C., \& El Khoury, R. (2014). Determinants of the dividend policy: an empirical study on the Lebanese listed banks. International Journal of Economics and Finance, 6(4), 240. http:// dx.doi.org/10.5539/ijef.v6n4p240

33. Malhotra, N. K. (2004). Marketing research: An applied orientation (4th ed.). Upper Saddle: PrenticeHall.
34. Marfo-Yiadom, E., \& Agyei, S. K. (2011). Determinants of dividend policy of banks in Ghana. International Research Journal of Finance and Economics, 61(61), 99-108. Retrieved from www.ccsenet.org/ journal/index.php/ijef/article/ download/11821/8322

35. Mercado-Mendez, J., \& Willey, T. (1995). Agency costs in the banking industry: An examination of ownership behavior, leverage and dividend policies. Journal of Economics and Finance, 19(3), 105-117. https://doi.org/10.1007/ BF02920617

36. Md Nassir, A., \& Mohamad, S. (1993). The Dividend and Earnings Behavior of Firms on the Kuala Lumpur Stock Exchange. Pertanika Journal of Social Sciences \& Humanities, 1(2), 171-177. Retrieved from http://www.pertanika.upm.edu.my/Pertanika\%20 PAPERS/JSSH\%20Vol.\%201\%20 (2)\%20Sep.\%201993/11\%20 PAGE\%20171-177.pdf

37. Miller, M. H., \& Modigliani, F. (1961). Dividend policy, growth, and the valuation of shares. The Journal of Business, 34(4), 411-433. http://dx.doi. org/10.1086/294442

38. Mohamed, E. K., Oyelere, P. B., \& Jifri, K. A. (2009). State corporate governance in Oman: Progress has been rapid, sophistication has increased, but there is still room for improvement. Journal of Taxation and Regulation of Financial Institutions, 22(4), 33-41.

39. Mohammed, S., \& Mohammed, M. (2012). A Worthy Factors Affecting Dividends Policy Decisions An Empirical Study on Industrial Corporations Listed in Amman Stock Exchange. Interdisciplinary Journal of Contemporary Research in Business, 4(5). Retrieved from http://journal-archieves23.webs.com/614622.pdf

40. Mollah, S. (2009). Testing partial adjustment dividend behavioral models in emerging markets: Evidence from pre-and postmarket reforms in Bangladesh. Global Journal of Business Research, 
3(1), 1-14. Retrieved from ftp:// ftp.repec.org/opt/ReDIF/RePEc/ ibf/gjbres/gjbr-v3n1-2009/GJBRV3N1-2009-1.pdf

41. Mookerjee, R. (1992). An empirical investigation of corporate dividend pay-out behavior in an emerging market. Applied Financial Economics, 2(4), 243-246. http://dx.doi. org/10.1080/758527107

42. Nizar Al-Malkawi, H. A. (2007). Determinants of corporate dividend policy in Jordan: an application of the Tobit model. Journal of Economic and Administrative Sciences, 23(2), 44-70. https://doi. org/10.1108/10264116200700007

43. Omet, G. (2004). Dividend policy behavior in the Jordanian capital market. International Journal of Business, 9(1), 288-300. Retrieved from https://ssrn.com/ abstract $=551082$
44. Pama, E. F., \& Babiak, H. (1968). Dividend policy of individual firms: An empirical analysis. Journal of the American Statistical Association, 63, 1132-1161. Retrieved from https://www.jstor. org/stable/pdf/2285874.pdf

45. Pandey, I. M., \& Bhat, R. (2007). Dividend behavior of Indian companies under monetary policy restrictions. Managerial Finance, 33(1), 14-25. https://doi. org/10.1108/03074350710715782

46. Qatar Country Report. (2015). Doha: Multigroup Qatar Ecomomic Outlook 2016-2018 (2016). Doha: Ministry of Development Planning.

47. Ray, S. (2012). Empirical testing of international Fisher effect in United States and selected Asian economies. Advances in Information Technology and Management, 2(1), 216-228. Retrieved from http://worldscien- cepublisher.org/journals/index. php/AITM/article/view/657/548

48. Rozeff, M. S. (1982). Growth, beta and agency costs as determinants of dividend payout ratios. Journal of financial Research, 5(3), 249-259. Retrieved from https://ssrn.com/ abstract $=820311$

49. Wei, G., Zhang, W., \& Xiao, J. Z. (2003). Dividends policy and ownership structure in China (EFMA 2004 Basel Meetings Paper). Retrieved from https://ssrn. com/abstract=463924 or http:// dx.doi.org/10.2139/ssrn.463924

50. Wooldridge, J. (2002). Econometric analysis of cross section and panel data. Massachusetts London: The MIT Press Cambridge (Lower sec. or less, 24, 21-0). Retrieved from https://jrvargas.files.wordpress. com/2011/01/wooldridge_j_2002_ econometric_analysis_of_cross_ section_and_panel_data.pdf 